\title{
Florilegio de Versiones Peruanas de Baudelaire
}

(Recogidas de reyistas peruanas por Estuardo Nuñez)

\section{LA MUSA ENFERMA}

Ven, pobre musa míal Están tus ojos

Hundidos $y$ poblados de visiones,

$Y$ han dejado on tu faz las emociones

Mezcla de surcos pálidos y rojos...

Qué genio ê qué demonio tét dá enojos

$Y_{\text {to inspira fatídicas canciones? }}$

Quizó el sueño que oprime corazones

En el tuyo dejó fríos despojos?

No, musa mía, no. Yo quiero verte

Con perfume de vida y de frescura;

Sea tu seno cual fecundo nido.

Donde aletee un sentimiento fuerte,

$Y$ que tu sangre corra limpia y pura

Con ritmo eterno de inmortal sonido.

(Versión de Edilberto Zegarra Ballón, fechada en Arequipa el 31 de mayo de 1892, y publicada en El Cosmos, de Arequipa, Número 1, junio de 1892). 


\section{PROLOGO DE UN LIBRO CONDENADO}

\section{(De Baudelaire)}

Lector sobrio y apacible

condescendiente y bucólico

apresúrate a arrojar

este libro condenado,

si acaso no has aprendido

la retórica del estro

donde mi ilustre maestro

el astuto Satanás.

Arrójale de tí, lejos,

Por las extrafias visiones

que flotan en mis canclones

histérico me creerás...

Mas si tus ojos no vagan

$y$ en infernal paroxismo

bajas conmigo al abismo,

léeme, después me amarás

alma curiosa que vives

un paraíso buscando,

y mientras vas caminando etras

lágrimas gvertiendo r vas:

de tí compasión imploro,

pues que la implore mereces

y si no me compadeces

|maldito por mí serás!

(Versión directa del francés por Domin. go del Prado, inserta en "El Modernismo, de Lima, No. 4, diciembre de 1900).

\section{ELEVACION}

Más allá delos valles, más allá de los lagos

de bosques, de montañas, de mares y de nubes;

más allá de los soles, tras los confines vagos

del éter, en que bogan estrellas y querubes. 


\section{$-68-$}

Alma mía, te mueves ágil y vagabunda, $y$, cual buen nadador que entre las ondas goza, surcas alegremente la inmensidad profunda, como una indefinible sensación voluptuosa.

Vuela, vuela, muy lejos de este ambiente dañino; sube a purificarte a más altas regiones, y hasta embriagarte bebe, como un licor divino, y mira la clara luz que emana de las constelaciones.

Tras los negros pesares de esta lucha afanosa y el implacable hastío que la existencia llena, feliz aquel que pueda, con ala vigorosa, lanzarse hacia la altura, luminosa y serena.

Feliz tú, que cantando, como la alondra, asciendes, hacia el cielo, alma mía, y/a la aurora saludas. Que te ciernes más alto que la yida y comprendes la lengua de las flores y de las cosas mudas!

\section{(Versión de Juan Tassara, publicada en "Balnearios", Barranco, 8 de febrero de 1914, No. 174).

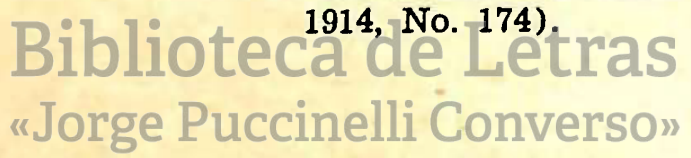

MOESTA ET ERRABUNDA

Dime, ¿a veces tu alma no se remonta, Agata, lejos del negro océano, de la inmunda ciudad, hacia otro mar, que un cielo más hermoso retrata, azul, claro, profundo, cual la virginidad?

Dime, ¿a veces tu alma no se -remonta, Agata?

¡El mar, el vasto mar, calma los sufrimientos! ¿Qué demonio ha dotado a este ronco cantor, que acompaña la orgía grandiosa de los vientos, de esta dulce y sublime función de arrullador? [El mar, el vasto mar, calma los sufrimientos! 
|Arrástrame vagón; elévame fragatal lejos del mundo que hace con lágrimas el lodo. ¿No es cierto que mil veces, tu alma murmura, Agata, al ver remordimiento, pena y dolor en todo? Arrástrame vagónl elévame fragatal

¡Cuán lejano, te encuentras, fragante paraíso, de amor y de alegría, bajo un cielo sereno; en que su sed quimérica la mente satisfizo, en que la voluntad nos acogió en su seno; jcuan lejano te encuentras, fragante paraísol

Oh verde paraíso de amores infantiles: carreras y canciones, ramilletes y besos: violines que se quejan tras ocultos pensiles, $y$ en la tarde, las cenas, en los bosques espesos!... -El verde paraíso de amores infantiles,

el paraíso casto de placeres furtivos, ¿Se encuentra ya más lejos que la India o la China? ¿Es posible evocar con gritos aflictivos, y despertar, al eco de una voz argentina, el paraíso casto de placeres furtivos?...

"Jorge P(Versióne de Juan Tassara, publicada en "Balnearios", Barranco, 15 de febrero de 1914, No. 175).

\section{TRISTEZA, DE LA LUNA}

Esta noche la Luna sueña con más delicia, cual bella que en un lecho de almohadones reposa, $y, a l$ entregarse al sueño, distraída acaricia, con la mano en contorno de sus senos de diosa.

Acostada entre blandos y sedosos encajes, en inefable éxtasis ve perderse su anhelo; y los ojos pasea por los tenues mirajes que, cual blancas florestas, se elevan hacia el cielo. 
Cuando sobre la tierra deja, con indolencia, caer alguna lágrima furtiva, en la presencia de un poeta que vela, tierna y piadosamente,

él recoge, en el hueco de la mano, esa perla, $y$ en el fondo de su alma se apresura a esconderla, lejos de la mirada del Sol, indiferente.

(Versión de Juan Tassara, publicada en "Balnearios", Barranco, 26 de abril de 1914, No. 158)

\section{EL ALBATROS}

A menudo, por broma, los rudos navegantes cogen a los albatros, grandes aves marinas, que siguen, indolentes compañeros errantes, a las naves que surcan las ondas cristalinas.

No bien sobre cubierta, pierden todas sus galas, y esos reyes del cielo, torpes y avergonzados, dejan caer sinegracia isus l poderosas glas, que arrastran cual si fueran remos abandonados.

[El ave, antes hermosa, cuán desmañada y feal Cuan grotesco el, ha poco, volador arrogantel... Con la pipa uno de ellos, el pico le golpea, otro imita cojeando, su marcha claudicante.

El Poeta aseméjase a este príncipe alado, que huracanes y flechas no logran arrollar; en medio de las burlas, proscrito y humillado, [sus alas de gigante le impiden caminar!

(Versión de Juan Tassara, publicada en "Balnearios", Barranco, 26 de abril de 1914, No. 158). 


\section{DON JUAN EN LOS INFIERNOS}

Cuando don Juan bajó al subterráneo río Y después que hubo dado su tributo a Carón, Como altanero Antístenes, pordiosero sombrío Empuñó los dos remos con vigor vengador.

Desceñidas las ropas y los senos pendientes Se agitaban mujeres bajo el cielo implacable, $Y$, cual rebaño innúmero de víctimas dolientes, Seguíanles, exhalando gemido interminable.

Sganarelle, burlesco, le cobraba su cuenta, En tanto que Don Luis con temblorosa mano, Mostraba de los muertos a la grey macilenta Al hijo audaz afrenta de su cabello cano.

Temblando entre sus tocas, la casta y magra Elvira, Al pérfido consorte que un día fué su amante Dijérase imploraba decisiva sonrisa En la que refulgiese su ternura distante.

Erecto con su armådura, un fantasmá severo El timón dirigía por la gris onda helada Mas el héroe impasible, feclinado en su acero Contemplaba la estela sin cuidarse de nada.

(Primera versión de Manuel Beltroy, publicada en Variedades, Lima, 23 de setiembre de 1922, No. 760). 